This is an Accepted Manuscript of an article published by Taylor \& Francis in Studies in Higher Education on 09/03/18, available online: https://www.tandfonline.com/doi/full/10.1080/03075079.2018.1445987 
What does 'quality' in higher education mean? Perceptions of staff, students and employers.

Dicker $\mathrm{R}^{1}$, Garcia $\mathrm{M}^{1}$, Kelly $\mathrm{A}^{1} \&$ Mulrooney $\mathrm{H}^{1,2}$.

${ }^{1}$ School of Life Sciences, Pharmacy \& Chemistry, Kingston University, Penrhyn Road, Kingston-upon-Thames KT1 2EE, UK

${ }^{2}$ Corresponding author. Dr Hilda Mulrooney, School of Life Sciences, Pharmacy \& Chemistry, Kingston University, Penrhyn Road, Kingston-upon-Thames KT1 2EE, UK. hilda.mulrooney@kingston.ac.uk 


\title{
What does 'quality' in higher education mean? Perceptions of staff, students and employers.
}

\author{
'Quality' in education is difficult to define. What is viewed as high quality by \\ staff, students and employers must be identified so that universities can articulate \\ their offer. Equally, helping students develop the graduate skills and attributes \\ that employers value is essential. This project explored quality in higher \\ education from the perspectives of undergraduate students, academic staff and \\ employers. 340 students, 32 staff and 17 employers completed their respective \\ questionnaires. Qualitative data was collected from students in focus groups. \\ Results showed that employers most highly valued graduate personal qualities, \\ while quality of teaching and learning, feedback and staff: student relationships \\ were highly rated by staff and students. Students, while positive about the \\ methods of teaching and learning used, expressed uncertainty about whether they \\ were receiving a high quality education. Higher education institutions and \\ academic staff must articulate the value of the academic offer more clearly to \\ their students.
}

Keywords: quality; perceptions; employability; teaching \& learning; personal qualities; relationships

\section{Introduction}

What is meant by 'quality' in higher education is unclear (Brockerhoff et al, 2015). It is a multidimensional term (Elton, 1998; Krause, 2012), simultaneously dynamic and contextual, but may also be perceived differently by different stakeholders (Schindler et al, 2015). Within higher education there are four main stakeholder groups: providers (e.g. funding bodies), users of products (e.g. students), users of outputs (e.g. employers) and employees of higher education (Schindler et al, 2015); quality is likely to be perceived differently from each viewpoint and is therefore relative (Harvey and Green, 1993). Others argue that quality must be considered from the perspectives of public 
accountability (value for money), the extent to which research outputs and student learning from higher education are socially desirable, and that quality has a transformative component for students, teachers and the culture of the institution (Biggs, 2001; Harvey and Knight, 1996). In addition, 'quality' has both tangible (e.g. course materials) and intangible (relating to student service) elements (Yeo, 2009).

Consumerisation of education may create or reinforce a negative perception of quality and whether higher education represents good value for money. What students perceive of as high quality in their education may not be clearly articulated (Hill, Lomas and MacGregor, 2003) or matched by what academics identify as valuable or what employers wish to see in graduates. Students who perceive themselves as receiving poor quality education may be less likely to engage and fulfil their academic potential, or may fail to continue their studies. Students may feel dissatisfied with their university education if what the university offers and delivers does not match their expectations, and if reflected in low National Student Survey and other survey results, consequent reputational damage. Staff understanding of high quality education may not match that of their students either in terms of content or delivery. Likewise if employers' expectations of the skills and competencies expected from high quality graduates are not met, this will impact negatively on student employability and employer relationships with higher education institutions. Identifying and disseminating what employers identify as high quality attributes may help students to develop key graduate attributes using the plethora of university support services available to them. Understanding what students identify as high quality or good value will help staff ensure the academic offer is framed in student-relevant terms. This is particularly important at a time when external ratings of universities such as the Teaching Evaluation Framework (TEF; http://www.hefce.ac.uk/lt/tef/) are likely to impact upon 
student choices and their perceptions of the extent to which any given higher education institution represents good value.

With the advent of student tuition fees in the UK in 1998 and the subsequent steady increase in tuition fees, students may consider themselves as consumers of education and indeed may be encouraged to do so by Government and the media (Brennan, 2012). However this overly simplistic description of what is a complex relationship ignores the requirement that for success students must take responsibility for and engage in their learning (Coates, 2006). Student engagement is linked to positive learning outcomes such as good grades and the development of critical thinking skills (Carini, Kuh and Klein, 2006). Learning, engagement and student retention are all linked (Carini, Kuh and Klein, 2006; Crisp and Cruz, 2009; Tinto, 2012). Therefore from a pedagogic perspective too, understanding different perspectives of quality is important.

The aim of this project was to ascertain what is perceived as quality in higher education by staff and students of a post-92 university Kingston University, and employers of graduates within the science sector, to identify commonalities and differences.

\section{Methods}

Ethics approval was granted by the Centre for Higher Education Research and Practice (CHERP) Research Ethics Committee of Kingston University. Three questionnaires were developed; one each for staff, students and employers. All participants received an information sheet explaining the aim of the research, why they had been chosen and how their data would be stored and used. 


\section{Student questionnaire}

Participating students received a questionnaire with a series of 15 statements about aspects of teaching and learning (Appendix 1). Participants were required to indicate whether they agreed, disagreed or were unsure about each statement. Data was coded and entered into an Excel spreadsheet; when demographic information was entered, the university identifier was removed so the dataset was anonymised.

\section{Staff and employer questionnaires}

The staff questionnaire comprised 27 statements; staff were asked to indicate whether they agreed or disagreed with each statement. Staff had the opportunity to add qualitative information about other factors they thought were important in the provision of a high quality education. Finally they were asked to identify the barriers which in their view, impact upon their ability to deliver a high quality education. The employer questionnaire contained 17 statements relating to their perceptions of the qualities of high quality graduates; employers were also asked to identify any additional important graduate attributes and to identify the single most important attribute of a high quality graduate. Both staff and employer questionnaires contained a brief tick-box demographic survey (gender, age, ethnicity, length of time in current job and job position). Staff and employer questionnaires are shown in Appendix 2 and 3 respectively.

\section{Focus groups}

Participants in all three groups were offered the option of attending focus groups to discuss key themes in more detail. One focus group was held with students; however to date limited interest has been expressed by staff and employers and no focus groups have been held. However staff and employers had the option of adding qualitative information to their questionnaire responses. 


\section{Distribution of questionnaires}

Large modules common to several degree pathways taken by first, second and final year students (levels $4,5 \& 6$ respectively) were identified and targeted in order to reach as many students as possible. Permission to distribute the questionnaires in class was sought from module leaders; a short verbal introduction to the project was given and information sheets distributed by the research team. Students who wished to participate did so, completing the activity in-class.

Foundation degree students (level 3) were reached at their end of year poster presentation event at the university. A short talk outlining the project was followed by distribution of the information sheets and questionnaires. All questionnaires were completed at the time and returned within the poster session.

Staff questionnaires including demographic information and the information sheet were emailed to all staff within the Science, Engineering and Computing (SEC) Faculty of the university. The faculty comprises approximately 50 academic members of staff. In addition paper copies of both were printed out and distributed to staff pigeonholes.

Questionnaires for employers were distributed at a number of external career guidance fairs.

\section{Data analysis}

All data was anonymised and entered into Excel spreadsheets, separately for staff, students and employers. For each group (staff, students \& employers), responses were collated into specific themes. A total of 5 themes were common to all three groups (specifically teaching \& learning, support, facilities, relationships and feedback). Staff and employers shared an additional 2 themes (co-curricular $\&$ institutional). Staff alone had questions related to timetables; employers alone had questions related to education 
\& personal qualities and students alone had a question related to peers. Students were also asked to respond to the statement: 'I think I am getting a high quality education at university' (possible responses were agree, disagree or unsure). Tables 1 and 2 show the themes and numbers of questions within each theme for staff, students and employers.

Table 1: Themes and numbers of questions within each theme for each group, categories shared by all groups

\begin{tabular}{|l|l|l|l|l|l|l|}
\hline Themes & T \& L & Support & Facilities & Relationships & Feedback \\
\hline Groups & \multicolumn{5}{|l|}{ Number of questions in each group for each theme } \\
\hline Staff & 7 & 5 & 5 & 3 & 3 \\
\hline Employers & 4 & 4 & 2 & 1 & 1 \\
\hline Students & 5 & 3 & 2 & 2 & 1 \\
\hline
\end{tabular}

${ }^{1} \mathrm{~T} \& \mathrm{~L}=$ Teaching \& Learning

Table 2: Themes and numbers of questions within each theme by group

\begin{tabular}{|l|l|l|l|l|l|l|}
\hline Themes & $\begin{array}{l}\text { Co- } \\
\text { curricular }\end{array}$ & Institutional & Timetable & Education & $\begin{array}{l}\text { Personal } \\
\text { qualities }\end{array}$ & Peers \\
\hline Groups & \multicolumn{2}{|l|}{ Number of questions in each group for each theme } & 0 & 0 \\
\hline Staff & 1 & 1 & 5 & 0 & 0 & 0 \\
\hline Employers & 2 & 3 & 0 & 2 & 2 & 1 \\
\hline Students & 0 & 0 & 0 & 0 & 0 & 0 \\
\hline
\end{tabular}

In order to analyse the data, 'yes' responses were scored 1 and 'no' answers scored 0 . For students alone, 'unsure' was coded -1 . Within each theme the scores for each individual were calculated and divided by the number of questions related to the theme for that group. For example the theme teaching and learning comprised 7 
questions for staff, 4 for employers and 5 for students. The overall teaching and learning score for staff was divided by 7 , that for employers by 4 and that for students by 5 to make scores comparable between groups.

As the data was non parametric, Kruskal-Wallis tests were carried out to explore differences in themes between staff, students and employers. Posthoc analysis was carried out using Dunn's p-values corrected using the Benjamini-Hochberg FDR method to identify specific differences between groups. For those themes relevant to only two of the groups, the Mann Whitney U test was used to identify differences in responses.

\section{Results}

\section{Participants}

A total of 340 students, 32 staff and 17 employers completed their respective questionnaires. Demographic descriptions of the student participants are shown in Table 3 , and staff and employer participants in Table 4. 
Table 3: Demographic description of student participants

\begin{tabular}{|c|c|c|c|c|c|}
\hline Level & $\begin{array}{l}\text { Total } \\
\text { Numbers } \\
\text { (\% of } \\
\text { total } \\
\text { sample) }\end{array}$ & $\begin{array}{l}\text { Males } \\
\text { Numbers } \\
(\%)\end{array}$ & $\begin{array}{l}\text { Females } \\
\text { Numbers } \\
(\%)\end{array}$ & $\begin{array}{l}\text { Age }(y) \\
\text { Mean } \pm \text { SD }\end{array}$ & Ethnicity $^{1}$ \\
\hline 3 & $\begin{array}{l}104 \\
(30.5 \%)\end{array}$ & $\begin{array}{l}39 \\
(37.5 \%)\end{array}$ & $\begin{array}{l}65 \\
(62.5 \%)\end{array}$ & $\begin{array}{l}21.9 \pm 4.6(\text { all }) \\
21.6 \pm 3.6(\mathrm{~F}) \\
21.9 \pm 4.6(\mathrm{M})\end{array}$ & $\begin{array}{l}27 \mathrm{~W}(26 \%) ; 31 \mathrm{~A}(30 \%) ; \\
28 \mathrm{~B}(27 \%) ; 14 \text { mixed } \\
(13 \%) ; 4 \text { other }(4 \%)\end{array}$ \\
\hline 4 & $\begin{array}{l}128 \\
(38 \%)\end{array}$ & $\begin{array}{l}43 \\
(34 \%)\end{array}$ & $\begin{array}{l}85 \\
(66 \%)\end{array}$ & $\begin{array}{l}22.1 \pm 5.0(\text { all }) \\
22.1 \pm 5.0(\mathrm{~F}) \\
21.9 \pm 3.9(\mathrm{M})\end{array}$ & $\begin{array}{l}31 \mathrm{~W}(24 \%) ; 45 \mathrm{~A}(35 \%) ; \\
32 \mathrm{~B}(25 \%) ; 12 \text { mixed } \\
(9 \%) ; 8 \text { other }(6 \%)\end{array}$ \\
\hline 5 & $\begin{array}{l}38 \\
(11 \%)\end{array}$ & $\begin{array}{l}11 \\
(29 \%)\end{array}$ & $\begin{array}{l}27 \\
(71 \%)\end{array}$ & $\begin{array}{l}22.2 \pm 4.1(\text { all }) \\
22.2 \pm 4.1(\mathrm{~F}) \\
22.6 \pm 3.8(\mathrm{M})\end{array}$ & $\begin{array}{l}16 \mathrm{~W}(42 \%) ; 11 \text { A }(29 \%) ; \\
6 \mathrm{~B}(16 \%) ; 2 \text { mixed }(5 \%) ; \\
3 \text { other }(8 \%)\end{array}$ \\
\hline 6 & $\begin{array}{l}70 \\
(20.5 \%)\end{array}$ & $\begin{array}{l}19 \\
(27 \%)\end{array}$ & $\begin{array}{l}51 \\
(73 \%)\end{array}$ & $\begin{array}{l}23 \pm 4.5(\text { all }) \\
23.3 \pm 4.2(\mathrm{~F}) \\
24.6 \pm 3.8(\mathrm{M})\end{array}$ & $\begin{array}{l}28 \mathrm{~W}(40 \%) ; 25 \mathrm{~A}(36 \%) ; \\
11 \mathrm{~B}(16 \%) ; 5 \text { mixed } \\
(7 \%) ; 1 \text { other }(1 \%)\end{array}$ \\
\hline Overall & $\begin{array}{l}340 \\
(100 \%)\end{array}$ & $\begin{array}{l}112 \\
(33 \%)\end{array}$ & $\begin{array}{l}228 \\
(66 \%)\end{array}$ & & $\begin{array}{l}105 \mathrm{~W} ; 112 \mathrm{~A} ; 77 \mathrm{~B} ; \\
33 \text { mixed; } 20 \mathrm{~ns} / \text { other }\end{array}$ \\
\hline
\end{tabular}

${ }^{1}$ Ethnicity: W= White; $\mathrm{A}=$ Asian; $\mathrm{B}=\mathrm{Black}$; ns = not stated 
All year groups were represented with the largest number of participants from Level 4 ( $n=128$ participants, $38 \%$ of the total student sample) and the smallest number from Level $5(n=38,11 \%$ of the total student sample). In each year group approximately two thirds of respondents were female and one third male, with no age difference seen by gender. Considerable ethnic diversity was apparent in the sample, in line with the rich ethnic diversity of the student body. Within each level a wide age range was seen so that differences in average age between each level were small. This was due to a small number of mature students within each level.

A total of 32 university staff and 17 employers took part. Employers tended to be younger than university staff, and had spent less time in their current post perhaps as a consequence of their relative youth. Ethnic diversity of the employers was limited, with the majority describing themselves as white. In contrast approximately one in five university staff described themselves as other than white. More female university staff than males took part, although participant numbers by gender within the employers group were almost equal. 
Table 4: Demographic description of staff and employer participants

\begin{tabular}{|c|c|c|c|c|c|}
\hline & $\begin{array}{l}\text { Males } \\
\text { Numbers, } \\
(\%)\end{array}$ & $\begin{array}{l}\text { Females } \\
\text { Numbers. } \\
(\%)\end{array}$ & $\begin{array}{l}\text { Age } \\
(\%)\end{array}$ & $\begin{array}{l}\text { Ethnicity }{ }^{1} \\
(\%)\end{array}$ & $\begin{array}{l}\text { Time in } \\
\text { current job } \\
(\%)\end{array}$ \\
\hline Staff & $13(41)$ & $19(59)$ & $\begin{array}{l}18-25 y: 0 \\
26-35 y: 22 \\
36-49 y: 63 \\
50-65 y: 16\end{array}$ & $\begin{array}{l}\text { W: } 78 \\
\text { A: } 6 \\
\text { Other: } 13 \\
\text { Ns: } 3\end{array}$ & $\begin{array}{l}<1 y: 3 \\
1-5 y: 32 \\
6-10 y: 42\end{array}$ \\
\hline Total & 32 & & & & \\
\hline Employers & $8(47)$ & $9(53)$ & $\begin{array}{l}18-25 y: 35 \\
26-35 y: 29 \\
36-49 y: 18 \\
50-65 y: 18\end{array}$ & $\begin{array}{l}\text { W: } 94 \\
\text { Mixed: } 6\end{array}$ & $\begin{array}{l}<1 y: 18 \\
1-4 y: 53 \\
\text { 5-6y: } 18 \\
>7 y: 12\end{array}$ \\
\hline Total & 17 & & & & \\
\hline
\end{tabular}

${ }^{1}$ Ethnicity: $\mathrm{W}=$ White; $\mathrm{A}=$ Asian; $\mathrm{B}=\mathrm{Black} ; \mathrm{ns}=$ not stated

\section{Differences between staff, students \& employers:}

Teaching \& Learning $(T \& L)$, Support and Facilities:

Kruskal Wallis tests indicated that there were significant differences between the three groups for all three themes (Table 5). The scores for staff \& students for T \& L were significantly higher than those for employers (respectively $p=0.0003 \& p=0.0009$, Dunn's p-value corrected by Benjamini-Hochberg FDR method). $76.5 \%$ of employers disagreed that the method of learning is a good marker of quality, whereas $91 \%$ of staff 
agreed that how material is delivered mattered and $74 \%$ of students agreed that use of a variety of teaching methods helped them to learn. $87.5 \%$ of students felt that the methods used to deliver their modules influenced their performance on those modules.

Both staff and employers rated support more highly than students ( $\mathrm{p}=0.000$ and $\mathrm{p}=0.002$ for staff vs. students and employers vs. students respectively). Both staff and students rated facilities significantly higher than employers $(p=0.000$ and $p=7.99 e-8$ respectively).

Table 5: Means $( \pm \mathrm{SD})$ and medians $( \pm \mathrm{IQR})$ for teaching \& learning $(\mathrm{T} \& \mathrm{~L})$, support and facilities for staff, students and employers

\begin{tabular}{|l|l|l|l|l|l|l|}
\hline & \multicolumn{2}{|l|}{ T \& L } & \multicolumn{2}{l|}{ Support } & \multicolumn{2}{l|}{ Facilities } \\
\hline $\begin{array}{l}\text { Kruskal } \\
\text { Wallis test } \\
\text { results: }\end{array}$ & H (df 2) 15.3, p=0.0005 & $\begin{array}{l}\text { H (df 2) 32.6, p=8.2e- } \\
08\end{array}$ & $\begin{array}{l}\text { H (df 2) 18.8, } \\
\mathrm{p}=0.00008\end{array}$ \\
\hline & $\begin{array}{l}\text { Means } \pm \\
\text { SD }\end{array}$ & $\begin{array}{l}\text { Median } \pm \\
\text { IQR }\end{array}$ & $\begin{array}{l}\text { Means } \pm \\
\text { SD }\end{array}$ & $\begin{array}{l}\text { Median } \pm \\
\text { IQR }\end{array}$ & $\begin{array}{l}\text { Means } \pm \\
\text { SD }\end{array}$ & $\begin{array}{l}\text { Median } \pm \\
\text { IQR }\end{array}$ \\
\hline Staff & $0.81 \pm 0.18$ & $0.86 \pm 0.29^{\mathrm{a}}$ & $0.65 \pm 0.32$ & $0.7 \pm 0.6^{\mathrm{c}}$ & $0.74 \pm 0.32$ & $0.9 \pm 0.5^{\mathrm{c}}$ \\
\hline Employers & $0.41 \pm 0.26$ & $0.4 \pm 0.4^{\mathrm{a}, \mathrm{b}}$ & $0.56 \pm 0.23$ & $0.5 \pm 0.25^{\mathrm{b}}$ & $0.27 \pm 0.31$ & $0.0 \pm 0.5^{\mathrm{b}}$ \\
\hline Students & $0.69 \pm 0.32$ & $0.8 \pm 0.4^{\mathrm{b}}$ & $0.11 \pm 0.61$ & $0.33 \pm 1.0^{\mathrm{b}, \mathrm{c}}$ & $0.68 \pm 0.52$ & $1.0 \pm 0.0^{\mathrm{b}, \mathrm{c}}$ \\
\hline
\end{tabular}

${ }^{a}$ Statistically significant difference between staff \& employers, p=0.0003 (T \& L), $\mathrm{p}=0.000$ (facilities), Dunn's $\mathrm{p}$ value adjusted by Benjamini-Hochberg

${ }^{\mathrm{b}}$ Statistically significant difference between students \& employers, $\mathrm{p}=0.0009$ (T \& L), $\mathrm{p}=0.002$ (support), $\mathrm{p}=7.99 \mathrm{e}-8$ (facilities), Dunn's $\mathrm{p}$ value adjusted by BenjaminiHochberg

${ }^{\mathrm{c}}$ Statistically significant difference between staff \& students; $\mathrm{p}=0.00002$ (support), Dunn's $p$ value adjusted by Benjamini-Hochberg 


\section{Relationships and Feedback:}

Kruskal-Wallis tests showed significant differences between the three groups for both themes as follows (Table 6). Relationships were rated significantly higher for employers than staff or students ( $\mathrm{p}=0.02$ for both). Students rated feedback significantly higher than staff $(\mathrm{p}=0.008) .53 \%$ of employers disagreed that the quality of feedback was a good marker of quality in higher education compared with $15 \%$ of staff. $72 \%$ of students agreed that the quality of feedback they received helped them to do better.

Table 6: Means $( \pm$ SD) and medians $( \pm$ IQR) for relationships and feedback for staff, students and employers

\begin{tabular}{|l|l|l|l|l|}
\hline \multicolumn{2}{|l|}{ Relationships } & Feedback \\
\hline $\begin{array}{l}\text { Kruskal } \\
\text { Wallis test } \\
\text { results }\end{array}$ & \multicolumn{2}{|l|}{$\mathrm{H}(\mathrm{df} 2) 7.13, \mathrm{p}=0.03$} & $\mathrm{H}(\mathrm{df} 2) 10.58, \mathrm{p}=0.005$ \\
\hline & Means $\pm \mathrm{SD}$ & Median $\pm \mathrm{IQR}$ & Means $\pm \mathrm{SD}$ & Median $\pm \mathrm{IQR}$ \\
\hline Staff & $0.81 \pm 0.27^{\mathrm{a}}$ & $1.0 \pm 0.33^{\mathrm{a}}$ & $0.52 \pm 0.35^{\mathrm{c}}$ & $0.33 \pm 0.67^{\mathrm{c}}$ \\
\hline Employers & $1.0 \pm 0.0^{\mathrm{a}, \mathrm{b}}$ & $1.0 \pm 0.0^{\mathrm{a}, \mathrm{b}}$ & $0.47 \pm 0.51$ & $0.0 \pm 1.0$ \\
\hline Students & $0.78 \pm 0.40^{\mathrm{b}}$ & $1.0 \pm 0.5^{\mathrm{b}}$ & $0.55 \pm 0.78^{\mathrm{c}}$ & $1.0 \pm 1.0^{\mathrm{c}}$ \\
\hline
\end{tabular}

${ }^{\text {a }}$ Statistically significant difference between staff \& employers, p=0.02 (relationships),

Dunn's $\mathrm{p}$ value adjusted by Benjamini-Hochberg

${ }^{\mathrm{b}}$ Statistically significant difference between students \& employers, $\mathrm{p}=0.02$

(relationships), Dunn's p value adjusted by Benjamini-Hochberg

${ }^{\mathrm{c}}$ Statistically significant difference between staff \& students; $\mathrm{p}=0.008$ (feedback),

Dunn's p value adjusted by Benjamini-Hochberg 
Co-curricular and Institutional:

Mann Whitney U tests indicated no significant differences for co-curricular activities between staff and employers, whereas scores for the institutional category were significantly higher $(\mathrm{p}=0.0004)$ for employers than staff.

Table 7: Means ( \pm SD) and medians $( \pm I Q R)$ for co-curricular and institutional for staff and employers

\begin{tabular}{|c|c|c|c|c|}
\hline & \multicolumn{2}{|l|}{ Co-curricular } & \multicolumn{2}{|l|}{ Institutional } \\
\hline \multirow{2}{*}{$\begin{array}{l}\text { Mann } \\
\text { Whitney U } \\
\text { test results }\end{array}$} & \multicolumn{2}{|c|}{$Z$ score $1.44, p=1.43$} & \multicolumn{2}{|c|}{$Z$ score $-3.56, p=0.0004$} \\
\hline & Means \pm SD & Median $\pm \mathrm{IQR}$ & Means \pm SD & Median $\pm \mathrm{IQR}$ \\
\hline Staff & $0.69 \pm 0.5$ & $1.0 \pm 1.0$ & $0.19 \pm 0.4$ & $0 \pm 0^{\mathrm{a}}$ \\
\hline Employers & $0.59 \pm 0.2$ & $0.5 \pm 0.0$ & $0.41 \pm 0.14$ & $0.33 \pm 0.0^{\mathrm{a}}$ \\
\hline
\end{tabular}

${ }^{a}$ Statistically significant difference between staff \& employers, p=0.0004 (institutional), Mann Whitney U 2-tailed test

\section{Individual categories}

Personal qualities were rated highly by employers $(0.82 \pm 0.30$, mean \pm SD) while education was rated less highly $(0.53 \pm 0.3$, mean \pm SD). $94 \%$ of employers agreed with the statement that motivated graduates were a good marker of quality in higher education; in contrast only $23.5 \%$ of employers agreed that degree classification was a good marker.

The average score for timetables given by staff was relatively low $(0.38 \pm 0.23$, mean $\pm \mathrm{SD})$.

Students rated the effect of interactions with peers on the quality of their learning relatively highly $(0.76 \pm 0.62$, mean $\pm \mathrm{SD})$. However in response to the 
statement 'I feel that I am getting a high quality education', the mean \pm SD was $0.56 \pm$ 0.79. This relatively low score was driven by a high number of 'unsure' responses (unsure responses scored -1). Of the total respondents, $19 \%$ were unsure, $6 \%$ disagreed and $75 \%$ agreed that they were getting a high quality education.

\section{Focus groups - students}

Three focus groups were held with undergraduate students, one each with five Level 4, 5 and 6 students. Major themes which emerged included the importance of staff who were enthusiastic and approachable. A perception of caring staff that 'want you to succeed' emerged as a major positive factor, whereas the converse, staff who were not approachable had a major negative effect. Polarised views of some staff were expressed. The positive impact of support services such as library and IT as well as career guidance services was acknowledged. In terms of negative factors, delays in replacing staff who left were perceived to have a negative effect on the quality of education received, as were staff seen as unenthusiastic or uncaring. In some cases staff leaving impacted upon particular schemes, singled out by students as having been badly affected. Concern over the impact of large group sizes on quality, common particularly in common first and second year modules, was expressed.

\section{Qualitative results - staff}

Staff were asked to identify in their own opinion what the biggest barriers to delivering a high quality education are (Table 8). The results showed clear commonalities among participants which fell into three broad categories: institutional barriers, barriers related to resources and barriers related to students. Institutional issues such as lack of time, excessive administration, workload, lack of adequate laboratory facilities and poor timetabling were most frequently mentioned. Also frequently mentioned were micromanagement, the role of senior management, staff shortages, constant changes and 
unequal workloads. Resource issues included lack of time as well as specific resources such as lab facilities, while student-related issues included lack of attendance and lack of responsibility.

Table 8: Barriers to delivering a high quality education from a staff perspective

\begin{tabular}{|c|c|c|}
\hline Category & Barrier identified & $\begin{array}{l}\text { Number of times mentioned (\% } \\
\text { of total responses) }\end{array}$ \\
\hline \multirow[t]{7}{*}{ Institutional } & $\begin{array}{l}\text { Excessive administration, } \\
\text { bureaucracy \& micromanagement }\end{array}$ & $13(18)$ \\
\hline & $\begin{array}{l}\text { Workload (quantity \& unequal } \\
\text { distribution) }\end{array}$ & $9(12.5)$ \\
\hline & Lack of support & $6(8)$ \\
\hline & Conflicting priorities & $3(4)$ \\
\hline & Timetabling & $3(4)$ \\
\hline & Constant change & $2(3)$ \\
\hline & Poor staff morale & $2(3)$ \\
\hline \multirow[t]{4}{*}{ Resources } & Large groups & $6(8)$ \\
\hline & $\begin{array}{l}\text { Lack of facilities (physical \& } \\
\text { budgets) }\end{array}$ & $8(11)$ \\
\hline & Lack of time & $7(10)$ \\
\hline & $\begin{array}{l}\text { Lack of staff, staff turnover \& } \\
\text { high staff: student ratio }\end{array}$ & $7(10)$ \\
\hline \multirow[t]{4}{*}{ Student } & $\begin{array}{l}\text { Lack of attendance \& lack of } \\
\text { student responsibility }\end{array}$ & $3(4)$ \\
\hline & Unrealistic student expectations & $2(3)$ \\
\hline & Low quality students & $1(1.5)$ \\
\hline & Total & $72(100)$ \\
\hline
\end{tabular}




\section{Qualitative results: employers}

Employers were asked to identify the single most important attribute of a high quality graduate. Notably, all respondents chose personal qualities such as enthusiasm, dedication, ambition, attitude, confidence \& curiosity.

Table 9: Most important graduate attributes identified by employers

\begin{tabular}{|l|l|}
\hline Quality & Numbers (\%) \\
\hline $\begin{array}{l}\text { Personal qualities: enthusiastic, determined, outgoing, tenacious, } \\
\text { listens, work ethic, questions \& challenges, confident }\end{array}$ & $28(49)$ \\
\hline Ambition: drive \& passion, self-belief & $12(21)$ \\
\hline $\begin{array}{l}\text { Realism: prepared to start at the bottom \& do small jobs, sees bigger } \\
\text { picture, learns on the job }\end{array}$ & $7(12)$ \\
\hline Skills: literacy \& numeracy, articulate, educated & $4(7)$ \\
\hline Interpersonal skills & $4(7)$ \\
\hline Knowledge \& experience & $2(3.5)$ \\
\hline Total & $57\left(99.5^{*}\right)$ \\
\hline
\end{tabular}

*Percentages rounded to nearest whole numbers

\section{Discussion}

Both teaching and learning and academic facilities were rated more highly by academic staff and students than employers. Similarly Green (1994) suggested a stakeholderrelevant aspect of quality; for students and teachers this related to the process of education, whereas for employers it related to the outputs. Whereas students and staff emphasise the quality of the student experience, employers emphasise employability (Harvey and Knight, 1996). Employability can be defined as the capacity to get and 
keep fulfilling work (Hillage and Pollard, 1998). Similarly to our findings, the subject of study may not be of relevance to most employers (Purcell and Pitcher, 1996). Instead the achievement of a degree in higher education may be considered a tool which equips graduates for future learning, as part of a lifelong learning model (Yorke, 1999). It is unsurprising that employers were less concerned in this study with the nuts and bolts of everyday teaching and learning than either staff or students. For employers the end product is of more relevance; it is a given that those called for interview will have achieved a basic minimum standard as evidenced by their degree. At that point the personal attributes of the individual; how they are likely to perform in the world of work and how they will work and communicate with a diverse range of other team members, becomes critical. Our findings illustrate this; for employers the most important attributes of high quality graduates were personal skills. This has also been shown by others (O’Leary, 2016; HECSU and AGCAS, 2015). Some individuals will be inherently skilled in these areas, but our findings highlight the important role of universities in helping all students to develop and demonstrate personal skills, perhaps through co-curricular activities or group assignments where opportunities to work together effectively are given. However it is not clear that students themselves recognise how important these skills are, and work is needed to ensure that they understand what skills they are developing through different assignments, activities and tasks, and why it is important that they can demonstrate them (Green, Hammer and Star, 2009).

Surprisingly, academic staff and employers both rated support significantly higher than students did. The statements related to support in the student questionnaire were confined to support networks (e.g. career guidance and support), whereas those in the staff questionnaire related to academic, career \& lifestyle support as well as provision of extra activities to support learning (e.g. talks, visits). Within the employer 
questionnaire the two support statements related to access to information (e.g. library, intranet) and provision of career guidance. It may be that not all students understand the importance of career guidance provision until they actually need it; if it lacked personal relevance at the time they filled in the questionnaire, they may not have understood why it matters. The provision of career support to students is important; part of graduate employability depends on graduates having assets (e.g. knowledge, skills and attitudes) and being able to present these to employers (Hillage and Pollard, 1998). Provision of careers advice is one part of enhancing student employability (Knight and Yorke, 2003). However university support encompasses far more than simply career guidance; it also includes the Personal Tutor Scheme, academic, library and study support. All of these help students to become self-directed learners, enhancing their employability (Nicol, 2010), a priority for higher education (Tomlinson, 2012).

The quality of the learning partnership between academic staff and students may depend on the individual relationships developed between staff and students. $95 \%$ of all students surveyed agreed with the statement that 'the lecturers I have impact upon my learning'. Since students and teachers are jointly responsible for the achievement of learning outcomes (Biggs, 2001), this is unsurprising. American data shows that degree completion and persistence are enhanced when students perceive that faculty members care about them and about their teaching (Pascarella and Terenzini, 2005). Others have shown that the competence of academic staff was considered to be the most important dimension of quality by undergraduate students (Munasinghe and Rathnasiri, 2011). Investment in learning is not solely the province of the learner. Learning and teaching are both deeply personal as well as professional activities, and it is unsurprising that relationships formed in the classroom impact upon learning. The quality of the teaching experience is important to students while the quality of the programme matters to staff 
(Harvey and Green, 1993). Nonetheless both are interlinked; how the teaching material is organised and delivered to students can encourage their active engagement (NSSE, 2001), and high levels of learning and engagement are reported by students when collaborative learning methods, academically challenging material and enriching educational activities are used (Umbach and Wawrzynski, 2005). Teaching and learning, maintenance of contact hours with academic staff and investment in learning facilities are more highly rated than smaller class sizes by students, when given a choice (Neves and Hillman, 2016).

Statistically significant differences for feedback between staff and students were seen; surprisingly student mean scores were higher than those for staff (Table 4). However what is perceived as feedback may vary, and the three questions on feedback for staff related to the amount, quality and format of feedback given to students. Staff who disagreed that the amount and/or format of feedback given was an important marker of quality would have a low mean score for this category, which does not imply that they disagree with the importance of good quality feedback. However although students rated the teaching and learning methods used and the feedback given highly, a high degree of uncertainty in response to the question 'I feel that I am getting a high quality education' was shown. It is important that higher education institutions including academic staff clearly articulate the value of the academic offer to their students, to reduce this uncertainty.

Statistically significant differences between staff, students and employers for the relationships category were shown; however the questions in this category varied for each group. For employers 'relationships' comprised a single question relating to good links to industry. The fact that $100 \%$ of employers agreed that this was important 
demonstrates the essentiality of universities engaging with the wider community and encouraging staff and students to develop relationships external to the university.

The barriers to provision of higher education as described by academics are important. If as has been suggested frontline academics are the makers and shapers of quality policy, the transformational concepts of quality can be undermined by factors external to the learning environment (Newton, 2006). The context of higher education is continually changing, constraining institutions. It should be expected and acknowledged that these changes have the potential to impact negatively on student perceptions of quality, regardless of the extent to which academic staff try to mitigate them. Clearly the constant pace of change was viewed by staff as an important barrier to the provision of high quality education. Continuous change with little time to evaluate and assess its' impact, or even to think about how best to implement it, is challenging for staff and therefore also for students. It would be surprising if this were not reflected in surveys such as the National Student Survey. Our data demonstrates the frustration of staff who are in the frontline of trying to implement changes, whilst simultaneously mollify students who may not understand why it is necessary and need support to deal with it (as indeed do staff). Within focus groups students demonstrated that they are aware of aspects such as staff changes and the potential negative impact this may have. They were also unimpressed by large group sizes.

\section{Conclusions}

Clear differences in perceptions of what is quality in higher education between staff, students and employers were shown. Employers value highly the personal qualities of graduates and unanimously rate external links with industry as important markers of quality. In contrast they are less concerned with the class of degree obtained or the methods used to obtain it. For staff and students their relationships are highly rated, 
unsurprising given the importance of the learning partnership between staff and students. Students are aware of constant change and qualitative data suggests that some aspects of change (e.g. high staff turnover) are perceived as negatively impacting upon quality. For staff, the difficulties of providing high quality teaching and learning in a constantly changing environment, with a multitude of conflicting priorities was clearly articulated. It is essential that higher education institutions clearly articulate the links between skills and attributes considered important by employers and the tasks and activities used to develop them, to their students.

\section{Acknowledgments}

The authors are very grateful to the staff, students and employers who gave up their time to complete the questionnaires, and to the students who participated in the focus groups.

\section{References}

Biggs, J. 2001. 'The Reflective Institution: Assuring and Enhancing the Quality of Teaching and Learning'. Higher Education 41: 221-238.

Brennan, J. 2012. 'The Changing Uses and Impact of Quality Assurance'. Talking about Quality 2: 1-11.

Brockerhoff, L., Huisman, J. and Laufer, M. 2015. Quality in Higher Education: a literature review. Ghent: Centre for Higher Education Governance.

Carini, R.M., Kuh, G.D. and Klein, S.P. 2006. 'Student Engagement and Student Learning: Testing the Linkages'. Research in Higher Education 47(1): 1-32.

Coates, H. 2006. 'The Value of Student Engagement for Higher Education Quality Assurance'. Quality in Higher Education 11(1): 25-36.

Crisp, G. and Cruz, I. 2009. 'Mentoring College Students: A Critical Review of the Literature between 1990 and 2007'. Research in Higher Education 50(6): 525545.

Elton, L. 1998. 'Dimensions of Excellence in University Teaching'. International Journal for Academic Development 3(1): 3-11.

Green, D. 1994. What is Quality in Higher Education? Buckingham (Society for Research into Higher Education): Open University Press. 
Green, W., Hammer, S. and Star, C. 2009. 'Facing up to the Challenge: Why is it so hard to Develop Graduate Attributes?' Higher Education Research and Development 28(1): 17-29.

Harvey, L. and Green, D. 1993. 'Defining Quality'. Assessment and Evaluation in Higher Education 18 (1): 9-34.

Harvey, L. and Knight, P. 1996. Transforming Higher Education. Buckingham (Society for Research into Higher Education): Open University Press.

HECSU and AGCAS (2015) What do graduates do? Manchester: Higher Education Careers Services Unit and Association of Graduate Careers Advisory Services. http://www.hecsu.ac.uk/assets/assets/documents/wdgd_2015.pdf (accessed $12 / 08 / 17)$

Hill, Y., Lomas, L. and MacGregor, J. 2003. 'Students Perceptions of Quality in Higher Education'. Quality Assurance in Education 11(1): 15-20.

Hill, F. 2007. 'Feedback to Enhance Student Learning: Facilitating Interactive Feedback on Clinical Skills'. International Journal of Clinical Skills 1 (1): 2124.

Hillage, J. and Pollard, E. 1998. Employability: Developing a Framework for Policy Analysis. Research Brief 85. UK: Department for Education and Employment. Knight, P.T. and Yorke, M. 2003. 'Employability and Good Learning in Higher Education'. Teaching in Higher Education 8 (1): 3-16.

Krause, K-L. 2012. 'Addressing the Wicked Problem of Quality in Higher Education: Theoretical Approaches and Implications'. Higher Education Research and Development 31 (3): 285-297.

Munasinghe, M.A.T.K. and Rathnasiri, U.A.H.A. 2011. 'Undergraduates Perception on Quality of Higher Education'. International Conference on Qualitative and Quantitative Economics Research (QQE). Proceedings. Singapore: Global Science and Technology Forum.

National Survey of Student Experience (NSSE) 2001. Our Origins and Potential.

Indiana University School of Higher Education. Retrieved 08/08/17: http://nsse.indiana.edu/html/origins.cfm

Neves, J. and Hillman, N. 2016. The 2016 Student Academic Experience Survey. UK: Higher Education Academy.

Newton, J. 2006. What is Quality? $1^{\text {st }}$ European Forum for Quality Assurance, Munich. 
Nicol, D. 2010. The Foundation for Graduate Attributes: Developing Self-regulation through Self and Peer-Assessment. Scotland: Enhancement Theme Publication, QAA.

O'Leary, S. 2016. The Opportunities and Challenges for Employability-related Support in STEM Degrees. Horizons in STEM Higher Education Conference: Making Connections and Sharing Pedagogy. University of Leicester, 30 June to 1 July. Pascarella, E.T. and Terenzini, P.T. 2005. How College Affects Students: a Third Decade of Research (vol 2). San Francisco: Jossey-Bass.

Purcell, K. and Pitcher, I. 1996. Great Expectations: the New Diversity of Graduate Skills and Aspirations. Institute for Employment Research, University of Warwick.

Schindler, L., Puls-Elvidge, S., Welzant, H. and Crawford, L. 2015. 'Definitions of Quality in Higher Education: a Synthesis of the Literature'. Higher Learning Research Communications 5(3): 3-13. doi.org/10.18870/hlrc.v5i3.244

Tinto, V. 1993. Leaving College: Rethinking the Causes and Cures of Student Attrition ( $2^{\text {nd }}$ edition). Chicago: University of Chicago Press.

Tinto, V. 2012. Completing College: Rethinking Institutional Action. Chicago: University of Chicago Press.

Tomlinson, M. 2012. 'Graduate Employability: A Review of Conceptual and Empirical Themes'. Higher Education Policy 25: 407-431.

Umbach, P.D. and Wawrzynski, M.R. (2005) 'Faculty do Matter: The Role of College Faculty in Student Learning and Engagement'. Research in Higher Education 46(2): 153-184.

Yeo, R.K. 2009. 'Service Quality Ideals in a Competitive Tertiary Environment'. International Journal of Educational Research 48: 62-76. doi.org/10.1016/j.ijer.2009.03.004

Yorke, M. 1999. Editorial. Studies in Higher Education 24: 277-278. 


\section{Appendix 1: Student Questionnaire}

\section{$\underline{\text { Statements }}$}

Do you agree or disagree with the following statements in regards to the quality of your experience in higher education? Please circle ONE response for each statement; either A (Agree), D (Disagree) or U (Unsure)

1. The lecturers I have impact upon my learning

A D U

2. I feel I do better in modules that my favourite lecturers teach on A

D U

3. The accessibility of university facilities (eg. Library) makes my learning easier

A $\quad \mathrm{D} \quad \mathrm{U}$

4. I am aware of what support networks are available at university

A D U

5. It has improved my experience having support networks (eg. Career guidance) available to me

A $\quad \mathrm{D} \quad \mathrm{U}$

6. The methods used to deliver my modules influence how well I do in them

A $\quad$ D $\quad$ U

7. The interactions I have with my peers have improved my university experience

A $\quad$ D $\quad$ U

8. The university classroom and laboratory facilities are good markers of quality

A $\quad$ D $\quad$ U

9. I think I am getting a high quality education at university

A $\quad$ D $\quad$ U

10. The feedback I get in class and assignments helps me to do better

A $\quad$ D $\quad$ U

11. I am satisfied with the amount of contact I have with academic staff

A $\quad$ D $\quad$ U

12. I feel I have been made aware of my future career prospects

A $\quad \mathrm{D} \quad \mathrm{U}$

13. A variety of teaching methods are used to help me learn

A $\quad$ D $\quad$ U

14. I am challenged by what I am learning

A $\quad$ D $\quad$ U

15. My curriculum is relevant to me

A $\quad$ D $\quad$ U 
If yes, please write down your email address for the purposes of organizing the focus group only.

My email address: 


\section{Appendix 2: Staff Questionnaire}

\section{Quality in Higher Education project}

Please complete both parts of the following questionnaire, which seeks to identify staff, student and employers perceptions of quality in higher education.

\section{Part I: Your opinions}

1. What does 'good quality' in higher education mean to you? (please tick ALL that apply)

The time I have with students

Good classroom facilities

My timetable

My students timetable

Access to support for students (e.g. study and careers advice)

Access to practical help for students (e.g. medical, housing, counselling)

Good laboratory facilities

More lab practicals

More office hours

Less office hours

My relationship with my students

Access to information for students (e.g. Studyspace, library)

I.T. facilities

The university buildings

Approachability of staff

The cost of university fees

Extra activities offered to students (e.g. talks, visits, extracurricular activities)

How material is delivered to students (e.g. lectures, tutorials)

A curriculum that students can relate to

Up-to-date material

Knowledgeable staff

Enthusiastic staff

Multiple teaching methods 
The amount of feedback I give to students

The quality of feedback I give to students

The format of feedback I give to students

The Personal Tutor Scheme

Other/s (please

specify.

2. What are the biggest barriers to delivering a high quality education for students, in your opinion?

\section{Part II: About You}

\section{Demographic Questionnaire}

1. Gender

\begin{tabular}{|c|c|c|}
\hline Male & Female & Prefer not to say \\
\hline 1 & 2 & 3 \\
\hline
\end{tabular}

2. Age

\begin{tabular}{|c|c|c|c|c|c|}
\hline $18-25$ & $26-35$ & $36-49$ & $50-65$ & $66+$ & $\begin{array}{c}\text { Prefer not } \\
\text { to say }\end{array}$ \\
\hline 1 & 2 & 3 & 4 & 5 & 6 \\
\hline
\end{tabular}

3. Ethnicity

\begin{tabular}{|c|c|c|}
\hline White & \multicolumn{2}{|c|}{} \\
\hline British & Irish & Any other white background \\
\hline 1 & 2 & 3 \\
\hline
\end{tabular}

\begin{tabular}{|c|c|c|c|}
\hline Mixed & & & \\
\hline $\begin{array}{c}\text { White and Black } \\
\text { Caribbean }\end{array}$ & $\begin{array}{c}\text { White and Black } \\
\text { African }\end{array}$ & White and Asian & $\begin{array}{l}\text { Any other mixed } \\
\text { background }\end{array}$ \\
\hline 4 & 5 & 6 & 7 \\
\hline
\end{tabular}

\section{Asian or Asian British}

\begin{tabular}{|c|c|c|c|}
\hline Indian & Pakistani & Bangladeshi & Any other Asian background \\
\hline 8 & 9 & 10 & 11 \\
\hline
\end{tabular}




\begin{tabular}{|c|c|c|}
\hline Black or Black British & \multicolumn{2}{|c|}{} \\
\hline Caribbean & African & Any other Black background \\
\hline 12 & 13 & 14 \\
\hline
\end{tabular}

\begin{tabular}{|c|c|}
\hline Other Ethnic Groups & \multicolumn{1}{|c}{} \\
\hline Chinese & Any other ethnic groups \\
\hline 15 & 16 \\
\hline
\end{tabular}

\begin{tabular}{|c|}
\hline Not stated \\
\hline 17 \\
\hline
\end{tabular}

4. How long have you been in your current job? (years).

5. Please indicate your current position.

\begin{tabular}{|c|c|}
\hline Academic & Admin \\
\hline Library & Technical \\
\hline I.T/ Stude & \\
\hline
\end{tabular}

Other, please specify:

6. Would you like to take part in a focus group to discuss this in more detail?

Yes No

If 'Yes', please give your email address to arrange a mutually agreeable time:. 


\section{Appendix 3: Employer Questionnaire}

\section{Quality in Higher Education project}

Please complete both parts of the following questionnaire, which seeks to identify staff, student and employers perceptions of quality in higher education.

\section{Part I: Your opinions}

1.What does 'good quality' in higher education mean to you? (please tick/highlight $\underline{\text { ALL }}$ that apply, or delete those that do not)

Graduates who are motivated

Graduates with a first class honours or upper second degree

A university with nice buildings \& infrastructure

Staff who are knowledgeable and up-to-date

The cost of the fees charged

The curriculum on offer to students

Graduates who are literate and numerate

Graduates who are questioning

Good university facilities (e.g. library, I.T., laboratories)

Access to information for students (e.g. university intranet, library)

The methods of teaching used

Quality of feedback given to students by staff

Good links to industry

Support facilities (e.g. career guidance)

Extra activities offered to students (e.g. talks, visits, extracurricular activities)

Enthusiastic staff

Externally accredited programme

Other/s (please

specify 
2. What, in your opinion, are the most important attributes a high quality graduate

possesses?

\section{Part II: About You}

\section{Demographic Questionnaire}

\section{Gender}

\begin{tabular}{|c|c|c|}
\hline Male & Female & Prefer not to say \\
\hline 1 & 2 & 3 \\
\hline
\end{tabular}

4. Age

\begin{tabular}{|c|c|c|c|c|c|}
\hline $18-25$ & $26-35$ & $36-49$ & $50-65$ & $66+$ & Prefer not to say \\
\hline 1 & 2 & 3 & 4 & 5 & 6 \\
\hline
\end{tabular}

\section{Ethnicity}

\begin{tabular}{|c|c|c|}
\hline White & \multicolumn{2}{|c|}{} \\
\hline British & Irish & Any other white background \\
\hline 1 & 2 & 3 \\
\hline
\end{tabular}

\begin{tabular}{|c|c|c|c|}
\hline \multicolumn{3}{|c|}{ Mixed } & \multicolumn{3}{|c|}{$\begin{array}{c}\text { White and Black } \\
\text { Caribbean }\end{array}$} & $\begin{array}{c}\text { White and Black } \\
\text { African }\end{array}$ & White and Asian & $\begin{array}{c}\text { Any other mixed } \\
\text { background }\end{array}$ \\
\hline 4 & 5 & 6 & 7 \\
\hline
\end{tabular}

\begin{tabular}{|c|c|c|c|}
\hline \multicolumn{2}{|c|}{ Asian or Asian British } & \multicolumn{2}{|c|}{} \\
\hline Indian & Pakistani & Bangladeshi & Any other Asian background \\
\hline 8 & 9 & 10 & 11 \\
\hline
\end{tabular}

\begin{tabular}{|c|c|c|}
\hline \multicolumn{2}{|c|}{ Black or Black British } & \multicolumn{2}{|c|}{} \\
\hline Caribbean & African & Any other Black background \\
\hline 12 & 13 & 14 \\
\hline
\end{tabular}




\begin{tabular}{|c|c|}
\hline Other Ethnic Groups & \multicolumn{1}{|c}{} \\
\hline Chinese & Any other ethnic groups \\
\hline 15 & 16 \\
\hline
\end{tabular}

\begin{tabular}{|c|}
\hline Not stated \\
\hline 17 \\
\hline
\end{tabular}

6. How long have you been in your current job?

(years)......................................

7. What is your current position?

8. Would you like to take part in a focus group to discuss this in more detail? YesNo

If 'Yes', please give your email address to arrange a mutually agreeable time:. 